\title{
Maria Nowacka
}

Instytut Medycyny Wsi im. Witolda Chodźki w Lublinie, Lublin

ORCID: 0000-0001-9696-7467

e-mail: archeus@post.pl

Jerzy Kopania

Akademia Teatralna w Warszawie - Filia w Białymstoku, Białystok

ORCID: 0000-0002-5999-1713

e-mail: jerzykopania@o2.pl

\section{Charles-Augustin Vandermonde (1727-1762) i jego utopia eugeniczna}

Charles-Augustin Vandermonde nie jest zaliczany do wielkich postaci Oświecenia, a jego nazwisko jest rozpoznawalne tylko przez wąskie grono badaczy. $Z$ jednego powodu warto jednak zwrócić uwagę na jego postać i poglądy: mianowicie sformułował on utopijne propozycje dotyczące możliwości ulepszania człowieka, które właśnie w dzisiejszych czasach - okresie rozwoju genetyki i dużej popularności postaw transhumanistycznych - nabierają szczególnego znaczenia i skłaniają do refleksji. Francuski lekarz jest wyrazistym przykładem tego, jak szlachetne intencje czynienia ludzi lepszymi dzięki medycynie muszą prowadzić, jeśli miałyby być realizowane, do skutków tragicznych dla człowieka.

\section{1. Życie i dokonania}

Charles-Augustin Vandermonde urodził się 18 czerwca 1727 roku w Macao, mieście założonym przez Portugalczyków na terytorium Chin, nad 
Morzem Południowochińskim ${ }^{1}$. Jego ojciec, francuski lekarz Jacques-François Vandermonde, przybył tam w 1723 roku, by podjąć pracę jako lekarz i chirurg Francuskiej Kompanii Wschodnioindyjskiej. Jacques-François szybko się ożenił - jego małżonką została Espérance Cacilla, córka Portugalczyka z arystokratycznego rodu, ale „w posagu wniosła mu jedynie swą urodę i szlachetne urodzenie" ${ }^{2}$. Z tego związku przyszedł na świat Charles-Augustin; jego matka miała domieszkę krwi azjatyckiej, co okaże się istotne dla kształtowania się poglądów jej syna w kwestii doskonalenia gatunku ludzkiego ${ }^{3}$. Niestety matka zmarła, gdy chłopiec miał dwa lata, ojciec zaś, skonfliktowany z władzami miasta, powrócił do Francji około 1730 roku .

Inteligentny i żądny wiedzy chłopiec wzrastał w otoczeniu ludzi światłych i był wszechstronnie kształcony. W 1750 roku ukończył studia medyczne w Paryżu, podjął praktykę lekarska, z czasem został profesorem chirurgii na Wydziale Medycznym Uniwersytetu Paryskiego, cenzorem królewskim i lekarzem królewskiej armii. Instytut Boloński ${ }^{5}$ zaliczył go w poczet swych członków. W listopadzie 1755 roku został redaktorem „Recueil périodique d'observations de médecine, de chirurgie, et de pharmacie", pisma przeznaczonego dla szerokiego kręgu czytelników. Na łamach tego periodyku, który od 1757 roku ukazuje się pod nowym tytułem: „Journal de médecine, chirurgie, pharmacie”, prowadził działalność popularyzującą odkrycia medyczne, propagował higienę i zdrowy tryb życia; obecnie uznaje się go za jednego z pierwszych dziennikarzy medycznych. Wspaniale rozwijającą się karierę przerwała nagła choroba, jakiś rodzaj łagodnej gorączki, która okazała się jednak

${ }^{1}$ Ch.-A. Vandermonde'owi nie poświęcono dotąd odrębnej monografii. Poniższe informacje biograficzne podajemy głównie za: Nicolas-François-Joseph Eloy, Dictionnaire historique de la médecine ancienne et moderne (Mons: H. Hoyois, 1773), 474-477. Zamieszczone tam informacje były przedrukowywane lub wykorzystywane w dziewiętnastowiecznych encyklopediach i słownikach medycznych.

2 Eloy, Dictionnaire, 474.

3 "However, she brought him one more defining gift: being herself of Asian descent, she gave birth to a boy of mixed race"; Clara Pinto-Correia, João Lourenço Monteiro, "Science in Support of Racial Mixture: Charles-Augustin Vandermonde's Enlightenment Program for Improving the Health and Beauty of the Human Species", Endeavour 38, 1 (2014): 25. Charles-Augustin określany był przez współczesnych jako très bel homme; tamże, 26.

4 Więcej informacji na temat J.-F. Vandermonde'a i jego pobytu w Macao zob. Charles Ralph Boxer, "A Sino-French Medical Manuscript of 1730", The Indiana University Bookman, 11 (1973): 5-11.

5 Accademia delle Scienze dell'Istituto di Bologna. Towarzystwo naukowe założone w Bolonii w 1690 roku, prężnie działające w XVIII wieku; obecnie Instytut jest ściśle związany z Uniwersytetem Bolońskim. 
śmiertelna ${ }^{6}$. Charles-Augustin Vandermonde zmarł 28 maja 1762 roku w Paryżu, przeżywszy zaledwie trzydzieści pięć lat.

Krótkość życia sprawiła, że Vandermonde nie mógł rozwinąć pełni swych możliwości. Jego pierwszym dokonaniem na niwie naukowej był przekład dziełka o chorobach skóry, którego autor, włoski medyk Carlo Curzio, proponował ich leczenie za pomocą rtęci; książka ukazała się w Paryżu w 1755 roku pod tytułem Dissertation anatomique et pratique sur une maladie de la peau d'une espèce fort rare et fort singulière. W historii francuskiego Oświecenia zapisał się Vandermonde dwoma dziełami. Pierwsze to Essai sur la manière de perfectionner l'espèce humaine z 1756 roku, w dwu tomach; będzie ono przedmiotem naszych rozważań. Drugim jest Dictionnaire portatif de santé, również w dwu tomach, wydany w 1759 roku i potem wielokrotnie wznawiany ${ }^{7}$; pierwsze wydania ukazywały się anonimowo, później uznano pewność autorstwa Vandermonde'a ${ }^{8}$. Jaki cel postawił przed sobą autor, wskazuje on sam w barokowym rozwinięciu tytułu dzieła, wyjaśniając, że jest to słownik:

W którym każdy znajdzie wystarczającą wiedzę o wszystkich chorobach, o różnych oznakach szczegółowo charakteryzujących każdą z nich, o najpewniejszych sposobach zapobiegania im, jak też o najskuteczniejszych środkach ich zwalczania, a wreszcie o wszystkich wskazaniach koniecznych, aby samemu stać się swym własnym lekarzem. Zebranie wszystkich dzieł, tak starożytnych, jak i współczesnych, najbardziej znanych lekarzy, dopełnione mnóstwem szczegółowych przepisów oraz leków na wszelkie rodzaje chorób.

Takie słowniki medyczne stały się bardzo popularne w osiemnastowiecznej Francji; wpisywały się w oświeceniowy kult światła rozumu

${ }^{6}$ Przyczyna śmierci Ch.-A. Vandermonde'a pozostaje nieznana. W krótkiej notce biograficznej $\mathrm{w}$ jednym z osiemnastowiecznych słowników słynnych postaci podano, że przyczyną była super-purgation, czyli bardzo silna biegunka; zob. Nouveau Dictionnaire historique ou histoire abrégée de tous les hommes qui se sont fait un nom par des talens, des vertus, des forfaits, des erreurs, etc., vol. 7 (Caen: Le Roy, 1783): 509.

7 Zob. omówienie tego dzieła, ze szczególnym wskazaniem nowatorstwa Vandermonde'a w kwestii chorób zawodowych: Olivier Zeller, „Médecine des Lumières et risques professionnels: le Dictionnaire portatif de santé", w: Le travail avant la Révolution industrielle, Actes du 127 e congrès des Sociétés Historiques et Scientifiques, Nancy, 2002, ed. Maurice Hamon (Paris: CTHS, 2006): 127-137.

${ }^{8}$ Za wersję właściwą uznaje się wydanie drugie: Charles-Augustin Vandermonde, Dictionnaire portatif de santé, nouvelle édition (Paris: Vincent, 1760). Anonimowość tłumaczono tym, że Vandermonde jako cenzor królewski dopuszczał dzieło do druku; zob. Roselyne Rey, „La vulgarisation médicale au XVIIIe siècle. Le cas des dictionnaires portatifs de santé", Revue d'histoire des science 44, 3-4 (1991): 420. 
rozpraszającego mroki zabobonu i czyniącego człowieka zdolnym do autonomicznego rozwoju' .

Vandermonde chce ukazać, jakie warunki życia sprzyjają zachowywaniu dobrego zdrowia, oraz dać każdemu wiedzę pozwalającą na podejmowanie $\mathrm{w}$ jak największym stopniu samodzielnych działań terapeutycznych w sytuacji pogorszenia się stanu zdrowia. Swój Dictionnaire portatif de santé kończy obszernym wykazem alfabetycznym najpowszechniej występujących chorób, z podaniem ich charakterystycznych objawów, dzięki czemu człowiek doświadczający konkretnych dolegliwości będzie mógł rozpoznać, jaka choroba go dotknęła, a więc także podjąć właściwe leczenie. „Niepewność, w jakiej się znajdujemy zawsze, gdy zapadamy na jakąś chorobę, której dokładnej nazwy nie znamy, sprawia, że nie możemy skorzystać z pomocy, którą moglibyśmy znaleźć w książkach, jak też z podanych w nich różnych środków zaradczych" $^{\prime 10}$. Vandermonde podaje przykład: oto odczuwamy ból głowy, ale nie wiemy, czy jest to migrena, jakiś stan zapalny, nadmierny napływ krwi czy może ostra wilgotność (humeur âcre) kłująca i drażniąca błony mózgu; skorzystanie z podanego wykazu uwolni od niepewności. Zwiększanie wiedzy o własnym ciele i zachodzących w nim procesach zwiększa więc autonomię człowieka ${ }^{11}$.

Jako człowiek Vandermonde budził sprzeczne emocje. „Jego praktyka lekarska, mądra i prawie zawsze skuteczna, zapewniła mu znakomitą klientelę, jednak kłótliwy i roszczeniowy charakter przysporzył mu także licznych wrogów"12. Nie prowadził zresztą szerokiej praktyki, lecz „zamknął się w swym gabinecie i przyjmował jedynie ludzi ze świata nauki i kultury (hommes de lettres), o których sądził, że mogą mu być użyteczni"13. Autor tych słów podkreśla jednak, że Vandermonde pozostawał w przyjacielskich stosunkach ze swoimi pacjentami, a tych, których

9 Zob. Daniel Bonnot, „Les dictionnaires des sciences médicales au XVIIIème siècle. Du dictionnaire de la langue française au dictionnaire médical", Histoire des sciences médicales XLIX, 2 (2015): 193-196. Zdaniem autora niektóre z tych słowników deviendront de véritables classiques, wśród nich słownik Vandermonde'a; tamże, 195. Wskazuje się, że słowniki te pełniły pozytywną rolę, propagując zachowania prozdrowotne i zwalczając zabobony i przesądy, ale z drugiej strony zacierały różnicę między profesjonalną a popularną literaturą medyczną prowadząc $\mathrm{w}$ rezultacie do tworzenia przez medyków wiedzy nieprzeznaczonej dla laików; szerzej na ten temat, ze szczególnym uwzględnieniem Dictionnaire Vandermonde’a, zob. Rey, „La vulgarisation médicale au XVIIIe siècle": 413-433.

10 Vandermonde, Dictionnaire, vol. 2, 461.

11 Można by nieco ironicznie zauważyć, że współczesnymi dictionnaires portatifs de santé są informacje medyczne, które można znaleźć w Internecie, a których wielość, obszerność i szczegółowość zapewne jeszcze bardziej zwiększa naszą autonomię.

12 "Vandermonde (Charles-Augustin)”, hasło w: Dictionaire des Sciences Médicales. Biographie médicale, vol. 7 (C. L. Paris: F. Panckoucke, 1825): 397.

13 Eloy, Dictionnaire, 475. 
nie było stać na uiszczenie honorarium, leczył bezinteresownie. Zauważa też jednak, że względem swych przyjaciół był zbytnio wymagający, żądając od nich przykładnego spełniania obowiązków, i korzystał z każdej okazji, aby im wypomnieć ich przewinienia.

Nieco więcej pobłażania dla słabości innych spowodowałoby, iż jego towarzystwo nie byłoby tak ze sobą skłócone. Jednakże prawość (véracité) jego charakteru nie dopuszczała żadnych odchyleń, subtelności czy choćby najmniejszej sztuczności (artifice); albowiem sam mając wielkie serce, chciał widzieć innych otwartymi, więc najmniejsze żywiąc wątpliwości, stawał się podejrzliwy ${ }^{14}$.

Być może to właśnie ten nieprzejednany charakter był jednym ze źródeł jego marzeń o ulepszeniu gatunku ludzkiego.

\section{Marzenie o pięknym człowieku}

Treści medyczne zawarte $\mathrm{w}$ dwu dziełach Vandermonde'a są obecnie jedynie ciekawostką historyczna, świadectwem stanu medycyny w XVIII wieku. Jako takie stanowią materiał do badań nad rozwojem myśli biomedycznej, ale dla medycyny współczesnej nie mają żadnego znaczenia ${ }^{15}$. Inaczej należy ocenić poglądy dotyczące kwestii ulepszania gatunku ludzkiego zawarte w Essai sur la manière de perfectionner l'espèce humaine $^{16}$. To, co twierdzi Vandermonde, jest ciągle aktualne, ponieważ stanowi część składową ideologii eugenicznej.

14 Tamże, 476.

${ }^{15}$ Nie znaczy to jednak, że w swoim czasie nie odegrały roli inspirującej. Podkreśla się zwłaszcza ich wpływ na badania dotyczące dziedziczenia schorzeń. „Vandermonde changed how physicians thought about heredity. His work influenced both doctors and lay readers, and inspired an entire genre of social commentary about hereditary vices (his work was still being cited approvingly in the 1820s)"; Sean M. Quinlan, „Inheriting Vice, Acquiring Virtue: Hereditary Disease and Moral Hygiene in Eighteenth-Century France", Bulletin of the History of Medicine 80, 4 (2006): 663.

${ }^{16}$ Zob. Charles-Augustin Vandermonde, Essai sur la manière de perfectionner l'espèce humaine, vol. I-II (Paris: Vincent, 1756). Istnieje przedruk współczesny: Charles-Augustin Vandermonde, Essai sur la manière de perfectionner l'espèce humaine, ed. Rudy Le Menthéour (Paris: Classiques Garnier, 2015). Wszystkie cytaty poniżej podajemy za wydaniem z 1756 roku, dodając w nawiasach kwadratowych strony wydania współczesnego. 


\subsection{Struktura i treść dzieła}

Na dwutomowy traktat składają się cztery części, po dwie w tomie. Całość poprzedzona jest dość obszerną przedmową oraz rozważaniami wstępnymi o pięknie. W przedmowie Vandermonde przedstawia plan dzieła, przede wszystkim jednak wskazuje jasno i wyraźnie jego cel jest nim wyłożenie i omówienie działań medycznych, dzięki którym możliwe jest ulepszanie człowieka jako jednostki i jako gatunku.

Musimy odnowić zepsute źródło naszych nastrojów i naszych tchnień. Musimy wzmocnić nasze narządy, zmienić, umocnić i ulepszyć wszystkie sprężyny w naszej maszynie. Podążając tą drogą możemy odnieść sukces w przełamywaniu łańcucha najbardziej groźnych chorób i najbardziej burzliwych namiętności, a utrwalając w ludzkim gatunku piękno, siłę i zdrowie, możemy tam rozprzestrzenić zalążek cnoty i doprowadzić umysł do jego największej mocy ${ }^{17}$.

Ulepszanie jest więc rozumiane przez Vandermonde'a najszerzej, jak to możliwe, tzn. w aspekcie fizycznym, psychicznym, umysłowym i moralnym.

Rozważania o pięknie Vandermonde czyni z nadzieja, że czytelnikowi łatwiej będzie śledzić trudniejsze wywody o treści medycznej. Autor już w przedmowie podkreśla jednak związek między poczuciem piękna a oceną kondycji człowieka. „Słabość i choroby towarzyszą nam od kołyski i zgodnie współpracują nad naszym zniszczeniem. To dlatego większość ludzi, ofiar deformacji, z ubolewaniem dostrzega, jak rozkwitające w dziełach Stwórcy piękno więdnie w ich ciałach"18. W ujęciu Vandermonde'a kategoria piękna jest kategorią medyczną, analogicznie jak kategorie życia, zdrowia czy siły życiowej. „Starałem się udowodnić, że piękno było jedną z cech człowieka i że zawieramy w sobie streszczenie tego, co Autor natury rozprzestrzenił wszędzie"119. Nie chodzi więc o piękno w rozumieniu subiektywnym, wedle którego to, co jeden uważa za piękne, inny może uznać za brzydkie, lecz o piękno rzeczywiste (la beauté en réelle), będące przedmiotem poznania obiektywnego. "Gdyby piękno było jedynie jakimś urojeniem, mogłoby zwodzić nasze zmysły, ale nie mogłoby zniewalać naszego serca" ${ }^{20}$. Piękno istnieje obiektywnie, stanowi składnik rzeczywistości przyrodniczej, a w człowieku jest obecne w różnym stopniu - człowiek piękny to człowiek bez ułomności

17 Essai, vol. 1: VII [36].

18 Essai, vol. 1: III-IV [35].

19 Essai, vol. 1: [37].

20 „Si la beauté n'était qu'un fantôme, elle pourrait séduire nos sens, mais non captiver notre coeur"; Essai, vol. 1: 3 [43]. 
fizycznych, zdrowy, w pełni sił życiowych i psychicznych, a zarazem cnotliwy, tym samym zaś każde pomniejszenie którejś z tych właściwości to pomniejszanie piękna. Czynienie człowieka lepszym jest więc czynieniem go piękniejszym.

Vandermonde rozumie piękno zgodnie ze starożytną teoria, wedle której zasadza się ono na symetrii i proporcji części tworzących daną całość. Przyroda została stworzona wedle zasad symetrii i proporcji, a więc piękno jest $\mathrm{w}$ niej rozprzestrzenione wszędzie ${ }^{21}$; w szczególności tkwi ono w każdej ludzkiej rasie, w każdym kraju, pod każdą szerokością geograficzną. Może oczywiście być tak, że różne przyczyny sprawiają iż w jakichś warunkach czy okolicznościach więcej jest jednostek skażonych, pozbawionych właściwej im z natury proporcji i symetrii; jeżeli jednak nie potrafimy dojrzeć piękna tam, gdzie ono rzeczywiście jest obecne, i uznajemy za brzydkie to, co jest piękne, to przyczyną jest jedynie nasz brak wrażliwości czy właściwego wychowania. A ponieważ zamysłem Stwórcy było uczynienie piękną każdej rzeczy, więc naszym moralnym obowiązkiem staje się przywracanie piękna wszędzie tam, gdzie z jakichkolwiek powodów zostało ono skażone. W odniesieniu do człowieka oznacza to, że ludzi żyjących należy leczyć, a nowych płodzić dopiero po wykonaniu wszystkiego, co zwiększa szanse, iż będą piękni. Eugenika Vandermonde'a polega na kreacji ludzkiego piękna.

Rozważania o pięknie kończy Vandermonde rozdziałkiem omawiającym siłę fizyczną (la force). Jeżeli człowiek jest silny fizycznie, to nie znaczy, że jest zdrowy, jako że zdrowie zależy od bardzo wielu czynników. Jednak siła fizyczna zwiększa szanse na zachowanie zdrowia, ułatwia znoszenie cierpienia, przedłuża życie i może je czynić bardziej radosnym. Dlatego nie umieszczając jej na szczycie naszej hierarchii wartości, nie powinniśmy też jej lekceważyć; wprawdzie bowiem nie wzmacnia umysłu, ale wspiera ciało ${ }^{22}$. Powinniśmy brać przykład ze starożytnych Greków, którzy na równi dbali o kształcenie umysłu i ciała. Należy dbać o ciało, wzmacniać jego siłę, nie tylko z uwagi na własne zdrowie, lecz także na zdrowie potomstwa. Zdrowe ciała rodziców wydają na świat zdrowe dzieci. Zdrowie to cenny dar, który rodzice mogą podarować swoim dzieciom od narodzenia. A wówczas zobacza, jak siła i piękno ich ciał rozkwitają w ciałach ich dzieci, a moc ich umysłów rozwija się w umysłach ich dzieci. „Chociaż człowiek jest arcydziełem natury, można go uczynić jeszcze doskonalszym, dając mu od narodzin

${ }^{21}$ „La proportion, la symétrie sont des trésors que la nature a versés dans tous les climats, qui sont de tous les âges et de toutes les conditions"; Essai, vol. 1: 27 [55].

22 "Quoique la force paraisse un des plus plus faibles avantages de l'homme, on ne doit pas cependant la négliger, puisqu'elle peut prolonger la vie, en augmenter les agréments, ou en diminuer les peines. Si elle n'éleve point l'esprit, elle soutient le corps"; Essai, vol. 1: 48-49 [63]. 
siłę i piękno"23. Te końcowe słowa wstępnych rozważań o pięknie i sile są zarazem wprowadzeniem do programu eugenicznego rozwijanego przez Vandermonde'a w pierwszej części dzieła.

Część pierwsza traktatu zawiera omówienie kwestii rozmnażania się ludzi oraz warunków, jakie musi spełnić para, aby mieć dzieci piękne, czyli zdrowe, żywotne, dobrze zbudowane itd. To w tej części Vandermonde przedstawia swój program ulepszania gatunku ludzkiego poprzez działania zmierzające do wydawania na świat jak najpiękniejszych (najlepszych) dzieci. Wszelkie te działania oparte są na przeświadczeniu, że dzieci nie mogą być doskonałe (parfaits), jeśli rodzice nie będą takimi. W tej części dzieła Vandermonde wykłada program ulepszania człowieka - program z istoty swej eugeniczny; omówimy go w następnym punkcie naszych rozważań.

Druga część dzieła dotyczy higieny kobiety w ciąży. Przyszła matka, strażniczka drogocennego owocu, który wynagrodzi jej wszelkie cierpienia i stanie się podporą jej życia, musi postępować w sposób racjonalny, kierując się oceną, które z jej działań i zachowań są a które nie są korzystne dla płodu. Trzecia część dzieła dotyczy higieny narodzonego dziecka. Zawiera rozważania, jak właściwie postępować ze stworzeniem, które nie jest jeszcze zdolne do samodzielnego życia i nie potrafi kierować się własnym rozumem, a zatem należy niejako prowadzić go za rękę, by kroczyło ścieżką zdrowia.

Druga i trzecia część książki nie zawierają treści eugenicznych. Vandermonde omawia różne zachowania i działania prozdrowotne mające pozytywny wpływ na kobietę ciężarna, na płód w jej łonie oraz na nowo narodzone dziecko. Zgodnie z powszechnie akceptowanymi w jego czasach przekonaniami formułuje rady i zalecenia dla kobiet w ciąży dotyczące czystego powietrza, higieny, zdrowego trybu życia, odżywiania i picia, aktywności fizycznej, snu, ale także wskazania z zakresu higieny psychicznej i porady dotyczące porodu. W odniesieniu do narodzonego dziecka Vandermonde omawia kolejno takie zagadnienia, jak: używanie pieluszek, sen w kołysce, jakość powietrza, sposób karmienia, gimnastyka, sen i budzenie się, wypróżnianie się, rozwój uczuć, niewłaściwy, krępujący ciało strój. Wszystko to ma na celu zapewnienie jak najlepszego stanu zdrowotnego płodowi, a następnie noworodkowi, niemowlęciu i wzrastającemu dziecku. Możemy bardzo wiele zrobić, aby stać się lepszymi, tzn. piękniejszymi i zdrowszymi; wstępnym warunkiem

23 "Quoique l'homme soit le chef-d'oeuvre de la nature; on le rendroit encore plus parfait, en lui donnant en naissant pour héritage la force et la beauté"; Essai, vol. 1: 63-64 [68]. 
koniecznym jest uświadomienie sobie, że za wiele zła dotykającego człowieka on sam odpowiada ${ }^{24}$.

Czwarta, ostatnia część zawiera rozważania o ludzkiej zmysłowości. Rozpoczyna się od wskazania, jak wielką rolę w naszym życiu odgrywają skłonności, przyzwyczajenia i nawyki, do których wdrażamy się od najmłodszych lat ${ }^{25}$. Kierujemy się nimi najczęściej bez świadomości, jak wiele z nich jest szkodliwych dla zdrowia. Następnie autor omawia rodzaje władz zmysłowych - smak, węch, słuch, wzrok i dotyk. Podstawą rozważań jest sensualistyczna teoria poznania, wyrażająca się w tezie, że cała wiedza pochodzi od zmysłów, a zatem człowiek, który czyni dobry użytek ze swych zmysłów, ma prawdziwy ogląd rzeczywistości ${ }^{26}$. Vandermonde podkreśla zarazem, że mężczyzna i kobieta dysponują tym samym rodzajem i tym samym poziomem zmysłowości ${ }^{27}$. Wyprowadza z tego wniosek, że rodzice powinni taką samą wagę przywiązywać do rozwijania zdolności fizycznych i umysłowych synów i córek, a nawet domniemywa, że przy równym traktowaniu kobiety czynić będą większe postępy niż mężczyźni ${ }^{28}$. Celem wywodów zawartych w tej części jest przekonanie czytelnika, że powinien kierować się motywami racjonalnymi, czyli w tym wypadku prozdrowotnymi.

\subsection{Program eugeniczny}

Program, który dziś nazwalibyśmy eugenicznym, zawarł Vandermonde w części pierwszej swego dzieła. Składa się ona z sześciu rozdziałów zawierających rady i wskazówki, którymi mają kierować się osoby zamierzające zawrzeć związek małżeński, jeśli chcą spłodzić i wychować jak najlepsze potomstwo. W rozdziale pierwszym wskazane zostały za-

${ }^{24}$ "Nous voulons éviter le mal, et nous prenons le chemin pour le trouver"; Essai, vol. 2: 201-202 [283].

${ }^{25}$ „L'homme s'abandonne tout entier à ses impressions accoutumées, et n'obéit plus qu'au torrent qui l'entraîne. Habitués aux mêmes aliments, à la même conduite, à la même vie, nous trouvons unobstacle invincible dans le moindre objet qui nous détourne"; Essai, vol. 2: 204 [287].

${ }^{26}$ „Tous les hommes qui se sont appliqués dès l'enfance à faire un bon usage de ce sens, sont aussi ceux qui ont les idées les plus justes des choses"; Essai, vol. 2: $284-285$ [315].

27 „Les hommes et les femmes ont à peu près tous le même degré de sensibilité. Ils sont conformés l'un à l'instar de l'autre. Ce sont les mêmes sens, les mêmes organes, les mêmes nerfs"; Essai, vol. 2: 286 [315].

${ }_{28}$ „Si l'on cultivait leurs dispositions naturelles, elles feraient plus de progrès que nous, et elles réuniraient quelque jour tous les avantages du corps et tous, les talents de l'esprit"; Essai, vol. 2: 286-287 [315].

Zob. Anne C. Vila, Enlightenment and Pathology. Sensibility in the Literature and Medicine of Eighteenth-Century France (Baltimore and London: The Johns Hopkins University Press, 1998): 90. 
lety, które powinni mieć małżonkowie. Przede wszystkim małżeństwa nie należy zawierać $z$ uwagi na inny cel niż wydanie na świat jak najlepszych dzieci. Interesy majątkowe czy względy społeczne nie powinny skłaniać do podejmowania decyzji matrymonialnych. Jeżeli obecnie tak wiele dzieci nosi wady swych ojców i matek, to jest oczywiste, że brak tych wad u rodziców jest warunkiem koniecznym, aby nie pojawiały się one u ich dzieci. „Rodzice uczyniliby je idealnymi, gdyby sami byli idealni. Konieczne jest więc, aby wszystko, co nie ma wady fizycznej, znajdowało się w częściach niezbędnych obu płciom lub w organizacji reszty ciała" $^{29}$. Tak więc przyszli rodzice powinni mieć dobra, proporcjonalną budowę ciała, wszystkie jego części zdrowe i dobrze uformowane, jak też ani nie mieć nad wagi, ani nie być chorobliwie chudymi. Tak samo ważne jest, aby żadne z rodziców nie miało wrodzonych wad skóry, takich jak guzy, plamy, pryszcze czy trądzik, wszystko to bowiem przechodzi na noworodka. Vandermonde podkreśla, że usuwanie tych wad jest warunkiem koniecznym, by nie pojawiły się one u dziecka. „Moim celem jest, by uczynić ludzi doskonałymi, zabierając ich od kołyski i prowadząc do okresu dojrzewania; ale nie wyrażam głupiego mniemania, że chcę ich przekształcić, gdy już zostali uformowani, jako że wówczas ich wady zyskały prawa nabyte, których nie można kwestionować" ${ }^{\prime \prime 30}$.

W rozdziale drugim, bardzo krótkim, autor wyjaśnia, na co należy zwrócić uwagę $\mathrm{w}$ związku małżeńskim. Otóż wprawdzie natura nie wyznaczyła ludziom pory roku stosownej na prokreację, jednak i wysokie temperatury w lecie, i niskie w zimie osłabiają organizm; dlatego najwłaściwszą porą jest wiosna, jak na to wskazuje sama przyroda. Ale równie ważny jest czas, w którym małżonkowie oddają się czynnościom prokreacyjnym. Ponieważ we dnie często jesteśmy przemęczeni i często przejedzeni, co osłabia nasze ciało, najwłaściwsza dla wiadomych czynności jest noc, która odświeża ciało i wzmacnia je.

Trzeci rozdział dotyczy zasad, jakimi należy się kierować, kojarząc ze sobą kobietę i mężczyznę. Vandermonde zaczyna od stwierdzenia, że małżeństwo jest „najsłodszym” (le plus doux) związkiem, stanowiącym wsparcie społeczeństwa ${ }^{31}$. Opiera się ono na równości i wzajem-

29 „Les parents les rendroient parfaits s'ils l'étaient eux-mêmes. Il est nécessaire sur tout qu'ils n'aient aucun vice de conformation, soit dans les parties essentielle aux deux sexes, soit dans l'organisation du reste du corps"; Essai, vol. 1: 66 [71]. Te części niezbędne obu płciom to organa płciowe; niestety Vandermonde informuje, że nie będzie ich opisywał, i radzi zajrzeć do stosownych książek.

${ }^{30}$ „Mon but est de rendre les hommes parfaits en les prenant au berceau, et en les conduisant jusqu'à l'âge de puberté; mais je n'ai pas la folle présomption de vouloir les refondre quand ils sont formés, car pour lors leurs défauts ont acquis des droits légitimes que l'on ne peut contester"; Essai, vol. 1: 70 [72].

31 "Although Vandermonde does not fully explore the concrete application of his method as a means of social regeneration, it is clear that he conceives of the 
nym dopełnianiu się dwu płci i dlatego poligamia, której przykładem są haremy, to odrażający wyraz brutalnej dominacji mężczyzny nad zniewolonymi kobietami. „Małżeństwo, w postaci, w jakiej zostało ustalone $\mathrm{u}$ nas, jest stanem najbardziej odpowiednim dla człowieka, ponieważ hamuje bodźce ciała i zwiększa wzajemną miłość między obojgiem małżonków"32. I dlatego też owoce tego małżeństwa powinny być jak najpiękniejsze, a od małżonków w dużej mierze zależy, aby tak się stało.

Nie powinno być dużej różnicy wieku między małżonkami. Jest to szkodliwe dla obu stron, przede wszystkim jednak dla żony młodszej od męża, ponieważ nie zaspokaja on jej potrzeb w wystarczającym stopniu, sam zaś „karmi się i tuczy” (se nourrit et s'engraisse). Oczywiście musi odbić się to na zdrowiu potomstwa. Również zbyt młody wiek jest niewskazany dla zawierania związku małżeńskiego, ponieważ organizm nie osiągnął pełni swych mocy; w szczególności organizm zbyt młodej matki musi zużywać część płynów ustrojowych jako swój własny pokarm, więc pozostaje ich za mało, aby nakarmić płód, nadto zaś macica i miednica nie mają jeszcze właściwych rozmiarów, co naraża matkę na poronienie, a dziecko na urodzenie się martwym. Dlatego mężczyźni nie powinni zawierać związku małżeńskiego przed ukończeniem dwudziestego piątego roku życia, a kobiety, które rozwijają się szybciej niż mężczyźni, przed ukończeniem osiemnastego roku życia. Niestety lekceważenie tych oczywistych zasad jest powszechne. "Zbyt często tego rodzaju przykłady można zobaczyć w zawieranych zwyczajowo małżeństwach, dzięki którym ojcowie i matki chcą powiększać swój majątek; poświęcają tym samym swoje dzieci w kwiecie wieku dla podłego interesu, co często trzeba odpokutować" ${ }^{\prime \prime 3}$.

Szczególnie ważne jest, aby przyszli rodzice nie byli chorowici, obciążeni chorobami dziedzicznymi, zarażeni wirusem ospy, gruźlicy, szkorbutu lub rakowym, ponieważ wszystko to przejdzie na ich dzieci. „Ludzie słabowici, którzy się pobieraja nie powinni oczekiwać pięknych i silnych dzieci"34. Zdaniem Vandermonde’a źródłem wielu wad

conjugal unit as the support of the social order"; M. Winston, "Medicine, Marriage, and Human Degeneration in the French Enlightenment", Eighteenth-Century Studies 38, 2 (2005): 268.

${ }^{32}$ „Le mariage tel qu'il est établi parmi nous, est l'état le plus convenable à l'homme, puisqu'il met un frein aux impressions de la chair, et qu'il augmente l'amour réciproque entre les deux époux"; Essai, vol. 1: 75 [75].

${ }^{33}$ "On ne voit que trop souvent de ces sortes d'exemples dans les mariages de convenance, par lesquels les pères et mères veulent augmenter leurs biens; ils sacrifient leurs enfants dans la fleur de leur âge à un vil intérêt, dont il sont lieu souvent de se repentir"; Essai, vol. 1: 79 [77].

34 "Les gens valétudinaires qui se marient ne doivent pas s'attendre à avoir de beaux et de forts enfants"; Essai, vol. 1: 82 [78]. 
wrodzonych występujących $\mathrm{u}$ dzieci, głównie $\mathrm{u}$ tych urodzonych w dużych miastach, jest rozwiązły tryb życia (libertinage) rodziców. Młodość kieruje się swymi pragnieniami, nie zaś rozumem; nie idzie za głosem natury, lecz naturę chce zmusić do posłuszeństwa; dlatego niegodziwe życie rodziców staje się przyczyną złych skłonności, słabości i chorowitości dzieci.

Równie ważne jest, aby przyszli małżonkowie nie różnili się zbytnio wzrostem, waga, tusza, ponieważ dziecko będzie nieproporcjonalne lub zdeformowane. Należy unikać łączenia osoby jednookiej z osobą mającą oba oczy, kalekiej z prawidłowo zbudowana, tym bardziej głuchej $\mathrm{z}$ niewidomą. "Wszystkie takie złączenia są sprzeczne z piękną natura, a rezultat, który musi z nich wynikać, nie może być wzorem piękna"35. Dzieci przypominają rodziców zarówno w tym, co piękne, jak i w tym, co zdeformowane, a jeśli czasami różnią się od swych ojców i matek, to dlatego, że przejęły cechy swych dalszych przodków.

Skoro chcemy mieć piękne dzieci, to musimy do tego świadomie zmierzać i nie możemy losu naszego potomstwa pozostawiać przypadkowi. „Jeśli przypadek może zdegenerować gatunek ludzki, sztuka może go także udoskonalić" ${ }^{\prime \prime 6}$. Vandermonde wskazuje, że przecież nie tylko o tym wiemy, ale korzystamy z tego - niestety jedynie w odniesieniu do zwierząt. Wyhodowaliśmy wiele nowych gatunków zwierząt, łączymy w pary osobniki tak dobierane, aby ich potomstwo miało oczekiwane przez nas cechy. "Skoro udało nam się udoskonalić rasę koni, psów, kotów, kurczaków, gołębi, kanarków, dlaczego mielibyśmy nie podejmować żadnych prób w stosunku do gatunku ludzkiego?"37. Vandermonde stawia to pytanie jako retoryczne ${ }^{38}$.

Rozdział czwarty traktuje o kwestii krzyżowania ras. Vandermonde wychodzi od spostrzeżenia, że natura jest zmienna w kształtowaniu jednostek, ale stała w tworzeniu gatunków. „Wydaje się, że dała zwierzętom i roślinom razem ze zdolnością rozmnażania zdolność zmieniania się i udoskonalania, a rozpowszechniając wszędzie to, co piękne i dobre,

35 „Tous ces assemblages sont contraires à la belle nature, et le produit qui en doit résulter ne peut pas être le modele du beau"; Essai, vol. 1: 85 [79].

36 „Si le hazard peut faire dégénérer l'espèce humaine, l'art peut ausi la perfectionner"; Essai, vol. 1: 91-92 [81].

37 „Puisque l'on est parvenu à perfectionner la race des chevaux, des chiens, des chats, des poules, des pigeons, des sereins, pourquoi ne ferait-on aucune tentative sur l'espèce humaine?"; Essai, vol. 1: 94 [82].

38 Rudy Le Menthéour we wstępie do współczesnego wydania dzieła twierdzi, że jest to podejście nowatorskie: „La pratique est ancienne chez les éleveurs, mais l'idée d'une application à l'homme est nouvelle"; Rudy Le Menthéour, Introduction, w: Vandermonde, Essai Essai sur la manière de perfectionner l'espèce humaine, ed. Rudy Le Menthéour (Paris: Classiques Garnier, 2015): 17. Nie jest to prawdą, gdyż już Platon zalecał wzorować się na hodowcach; zob. niżej, przypis 58. 
pozostawiła nam moc modyfikowania wszystkiego na tysiąc różnych sposobów, bez odchodzenia jednak od oryginalnego wzorca" ${ }^{\prime 39}$. Daje to człowiekowi możliwość ulepszania jednostek $w$ ramach każdego gatun$\mathrm{ku}$, więc także gatunku ludzkiego. Człowiek czyni to z powodzeniem w odniesieniu do roślin i zwierząt, na przykład przystosowując rośliny i zwierzęta do innego klimatu, co zazwyczaj kończy się sukcesem po dwu lub trzech pokoleniach. Podobnie usiłuje człowiek z dobrym skutkiem krzyżować rasy. „Ciepły kraj powoduje wady, które nie występują w zimnych krajach, a zimny kraj wytwarza odchylenia zupełnie przeciwne do tych występujących w gorących krajach. Łącząc zwierzęta z tych dwóch klimatów, łączymy ich wzajemne cechy, a ich niedoskonałości niszczą się nawzajem"40.

Vandermonde wskazuje przy tym, że w procesie krzyżowania się ras należy nadto je odnawiać, ponieważ bez tego będą się degenerowały, przejmując wady właściwe dla klimatu, w którym żyją. „Dlatego konieczne jest odnowienie ras, krzyżowanie ich w każdym pokoleniu; to najlepszy sposób na udoskonalenie dzieł przyrody. Im bardziej zwierzęta będą pochodziły z przeciwnych klimatów, tym bardziej ich potomstwo będzie piękne i silne" ${ }^{\prime 1}$. Vandermonde ilustruje wywody przykładami udoskonalającej hodowli koni, owiec, psów.

Człowiek jest równie jak zwierzęta podatny na zmiany klimatyczne; może się wprawdzie przed nimi skuteczniej zabezpieczać, jednak jest bardziej na nie podatny, ponieważ zależne przecież od klimatu ilość i jakość pożywienia decydują o jakości płynów ustrojowych, co z kolei przesądza o jego temperamencie. Gatunek ludzki nie jest taki sam w każdym klimacie, ponieważ „różne pokarmy z różnych klimatów, zmieniając temperament, modyfikują nieskończenie doskonałości i niedoskonałości każdego bytu" ${ }^{\prime 2}$. To dlatego na przykład Hiszpanie i Anglicy tak bardzo różnią się temperamentami i te dwa narody nie mają ani takich samych zalet, ani takich samych wad. A stąd już można wyprowadzić prosty wniosek, że należy krzyżować rasy ludzkie tak jak krzyżujemy

39 „Il semble qu'elle ait donné aux animaux, aux végétaux, avec la faculté de se reproduire, celle de s'altérer et de se perfectionner, et qu'en répandant par-tout le beau et le bon, elle nous ait laissé le pouvoir de les modifier de mille manieres différentes, sans cependant nous écarter de l'empreinte originaire"; Essai, vol. 1: 99 [85].

${ }^{40}$ Un pays chaud fait naître des défauts que l'on n'a pas dans les pays froids, et le pays froid produit des excès tout opposés à celui des pays chauds. En assortissant les animaux de ces deux climats, on marie leurs qualités mutuelles, leurs imperfections se détruisent réciproquement"; Essai, vol. 1: 101 [85].

${ }^{41}$ „Il est donc nécessaire de renouveller les races, en les croisant à chaque génération; c'est le meilleur moyen de perfectionner les ouvrages de la nature. Plus les animaux seront de climats opposés, plus leur production sera belle et forte"; Essai, vol. 1: 103 [86].

42 "les aliments différens des divers climats, variant les tempéraments, modifient les perfections et les imperfections de chaque être à l'infini"; Essai, vol. 1: 107 [87]. 
zwierzęce. Rasę rozumie Vandermonde bardzo szeroko - z kontekstu jego rozważań wynika, że do odrębnych ras zalicza nawet poszczególne narody. Dlatego sądzi, że zawieranie związków małżeńskich w ramach jednego narodu musi prowadzić do degeneracji rasy; zapewne już pierwsi ludzie zauważyli, że związki w ramach tego samego plemienia (famille) powodowały degenerowanie się jednostek i że można temu zaradzić, wprowadzając obce rasy.

Swoje konstatacje Vandermonde ilustruje przykładami mającymi dowodzić, że krzyżowanie się ras skutkuje lepszym potomstwem, a kojarzenie związków $\mathrm{w}$ ramach jednej rasy prowadzi do degeneracji kolejnych pokoleń. Na przykład królewska krew jest zazwyczaj bardzo piękna (fort beau), ponieważ władcy zawierają małżeństwa z osobami krwi królewskiej z innych krajów ${ }^{43}$. Turcja jest krajem pięknych ludzi, ponieważ jest mieszanką wielu ludów. Persowie, którzy pochodzą od Tatarów, byliby brzydcy i źle ukształtowani, gdyby nie to, że przez długi czas dochodziło do mieszania się między nimi a Gruzinami i Czerkiesami. Tymczasem ludy łączące się tylko między sobą są brzydkie i źle ukształtowane, na przykład Gebrowie ${ }^{44}$, mieszkańcy prowincji położonych najbliżej Indii oraz Żydzi, którym Stary Testament zabrania poślubiać obcych. Wynika z tego wniosek praktyczny:

Przykłady wszystkich narodów są aż nadto wystarczające, aby udowodnić konieczność krzyżowania ras ludzkich w celu zapobieżenia ich degeneracji. Najbardziej rozsądni władcy powinni przyciągać cudzoziemców obietnicą nagród; nagradzając ich, sami wzbogacaliby się, a pozbawiając inne kraje najpiękniejszych ludzi i największych geniuszy, ponownie zasiedlali własne kraje osobnikami zdolnymi do ich obrony i sprawienia, by kwitła tam sztuka i nauka. Rzadko zdarza się, aby przypadkowe połączenie mężczyzny i kobiety o różnych klimatach powodowało powstanie istot zdeformowanych i pozbawionych geniuszu. Przeciwnie, zakładać należy, że najwięksi ludzie wyszli z tych związków, które tworzone były przez przypadek ${ }^{45}$.

43 Vandermonde wymienia przykładowo: „Polska z Francja, Francja z Hiszpanią. Niemcy, Węgry, Anglia zawierają związki krzyżowe"; Essai, vol. 1: 110 [88-89]. I konkluduje: "Aby zapewnić efekt krzyżowania się ras, musimy podziwiać efekt działania naszych królów i naszych książąt krwi”; Essai, vol. 1: 110-111 [89].

${ }^{44}$ Gebrowie to odłam Persów, który nie przyjął islamu, pozostając przy zoroastryzmie.

45 „L'exemple de toutes les nations n'est que trop suffisant pour prouver la nécessité où l'on est de croiser les races humaines, pour les empêcher de dégénérer. Les souverains les plus politiques devraient attirer les étrangers par l'appas des récompenses; en les gratifiant, ils s'enrichiraient eux-mêmes, et en dépeuplant les autres pays des plus beaux hommes et des plus grands génies, ils repeupleroient leurs états de sujets capables de les défendre et d'y faire fleurir les arts et les sciences. Il est rare que l'assemblage fortuit d'un homme et d'une femme de climats différents, produise des êtres difformes, et privés de génie. Il est au contraire à présumer que les 
Vandermonde dodaje, że każde krzyżowanie, nie tylko między ludźmi z różnych krajów, lecz także między osobami z różnych prowincji tego samego kraju, między mieszkańcami miast i wsi, mieszkańcami terenów różniących się klimatem, skutkuje lepszym potomstwem i zapobiega degeneracji. Ojcowie, którzy chcą mieć dzieci o pięknej i silnej budowie, powinni więc poszukiwać związku z obcymi kobietami i unikać łączenia się z tymi, które pochodzą z ich najbliższego otoczenia.

Rozdział piąty zawiera rozważania o rozmnażaniu. Vandermonde rozpoczyna wyrażeniem zdziwienia, że to, co natura ma najpiękniejszego i najciekawszego, pozostaje dla nas najciemniejsze. Najwięksi filozofowie i najbardziej oświeceni lekarze niewłaściwie podchodzili do badania przyrody i żywili całkiem błędne przekonania, w szczególności na temat rodzenia. Było tak przez wiele stuleci i dopiero od niedawna sytuacja się zasadniczo zmieniła dzięki temu, że spekulację zastąpiono doświadczeniem. Kolejni badacze wnosili swój wkład w poznawanie natury i wyjaśnianie mechanizmów zapłodnienia i rodzenia. Vandermonde wymienia osiągnięcia takich badaczy, jak między innymi: Fabrice d'Aquapendente, Ulisse Aldrovandi, William Harvey, Marcello Malpighi, Reinier De Graaf, Antonio Valisnieri, Antoni van Leeuwenhoek, Nicolaas Hartsoeker, John Needham, a przede wszystkim Georges Louis Leclerc de Buffon ${ }^{46}$. Szczególne znaczenie mają odkrycia tego ostatniego, ponieważ pozwoliły one wyjaśnić procesy zapłodnienia i powstawania płodu. Dzięki temu rozumiemy, dlaczego chcąc mieć piękne i silne dzieci, musimy dopasowywać do siebie dwie płcie pod względem ich cech, jakie są przyczyny dziedzicznych wad i w jaki sposób możemy sprawiać, by nie pojawiały się one u dzieci. Badania wymienionych przyrodników pozwoliły nam coraz lepiej rozumieć, jakie są zasady kierujące powstawaniem rozmaitych odmian zwierząt i na jakie sposoby możemy, różnicując zwierzęta, ulepszać je. Vandermonde znów stawia retoryczne pytanie: „Dlaczego nie działać także dla gatunku ludzkiego?" ${ }^{47}$.

Ostatni, szósty rozdział omawia kwestię podobieństwa dzieci do ojca i do matki. Vandermonde rozpoczyna od wskazania na zadziwiającą właściwość działania natury, polegającą na tym, że zróżnicowanie jednostek tak dalece idące, że nie ma dwu osobników identycznych, zawsze realizuje się $\mathrm{w}$ ramach niezmiennego wzorca gatunkowego.

plus grands hommes sont sortis de ces alliances formées par le hazard"; Essai, vol. 1: 113-114 [89-90].

${ }^{46}$ "Vandermonde [...] was the first to write a book applying Buffonian ideas about animal breeding to humans”; William Max Nelson, „Making Men: Enlightenment Ideas of Racial Engineering", American Historical Review 115, 5 (2010): 1364-1394.

${ }^{47}$ „Pourquoi ne travaillerait-on pas aussi pour l'espèce humaine?"; Essai, vol. 1: 155 [105]. 
Jego zdaniem jest tak dlatego, że podobieństwo opiera się na proporcji, a ponieważ różne czynniki powodują że u każdego osobnika poszczególne części rozwijają się niejednakowo, zmieniają się charakterystyki jednostkowe, ale wzorzec gatunkowy pozostaje taki sam. Rodzice przekazują więc dzieciom wzorzec gatunkowy, ale także swój indywidualny wzorzec, ten ukształtowany $\mathrm{w}$ ramach wzorca gatunkowego poprzez różnego rodzaju działania, którym oni podlegali w trakcie swego rozwoju. Tym, dzięki czemu to przekazywanie się realizuje, jest „,szczególna zgodność cząsteczek organicznych i ich wzajemne przenikanie się"48. Jeżeli cząsteczki organiczne mężczyzny są najbardziej aktywne, dziecko będzie wyglądało tak jak ojciec; jeśli zaś bardziej aktywne są cząsteczki kobiety, dziecko będzie podobne matki. Ale ponieważ dziecko jest rezultatem połączenia części i ojca, i matki, nie może całkowicie przypominać i jednego, i drugiego.

Wydawać by się mogło, że $\mathrm{w}$ takim razie dzieci powinny być odwzorowaniem ojca lub matki, a przynajmniej jednego z nich. Tak jednak nie jest z powodu nieproporcjonalnego rozwoju części - wszystkie części ciała podatne są na zmiany i każdego dnia zyskują nowe proporcje. Zdarza się też, że dzieci nie są podobne do rodziców, lecz do wujków, ciotek lub do dalszych krewnych. Zachodzi to wtedy, gdy w małżeństwie jedna osoba ma słabe lub źle ukształtowane cząsteczki organiczne, które zostają niejako wypierane przez silniejsze cząsteczki z linii drugiej osoby, a w rezultacie u dziecka ujawniają się cechy pochodzące z tej linii.

Wskazane mechanizmy działają także w wypadku ludzkiego umysłu, ponieważ nasza dusza myśli i rozumuje w zależności od wrażeń, jakie otrzymuje od ciała.

Tak więc włókna naszego mózgu i nerwów są rozłożone w taki sposób, aby uczynić nasze idee mniej lub bardziej żywymi, jak też dać nam mniej lub więcej bystrości. Jeśli cząstki organiczne ojca i matki są dobrze złączone, dobrze dopasowane, jeśli sprężyny są ciaśniejsze, wrażliwość będzie większa; a wręcz przeciwnie, gdy cząsteczki te są słabo zazębiające się, będą miały bardzo mało wigoru i spowoduja, że umysł będzie tępy ${ }^{49}$.

Pozwala to zrozumieć, jak jest możliwe zarówno to, że inteligentni rodzice płodzą inteligentne dzieci, jak i to, że głupi ludzie płodzą

48 „la conformation particulière des molécules organiques, et leur entrelacement réciproque"; Essai, vol. 1: 158 [107].

49 "Ainsi les fibres de notre cerveau et de nos nerfs sont disposées d'une manière à rendre nos idées plus ou moins vives, et à nous donner plus ou moins d'esprit. Si les particules organiques des père et mère sont bien unies, bien assorties, que les ressorts en soient plus serrés, la sensibilité sera plus grande; si au contraire ces molécules sont mollement engrénées, elles auront très peu de ressort, et rendront l'esprit obtus"; Essai, vol. 1: 167 [110]. 
inteligentne dzieci, albo to, że nieraz najwięksi geniusze byli głupimi dziećmi. Wynika z tego następujący wniosek praktyczny:

Aby więc płodzić dzieci inteligentne, należałoby być dobrze zbudowanym, posiadać subtelne i delikatne organy oraz postarać się złączyć z kimś, kto ma poziom umysłu proporcjonalny do naszego. W ten sposób złączenie cząstek organicznych będzie znacznie lepsze; bo jeśli siła myśli jest taka sama, prawdopodobne jest, że sprężystość we włóknach jest prawie równa. Jeśli zamiast tego $\mathrm{w}$ małżeństwie jedna $\mathrm{z}$ dwóch osób ma umysł wyższy od drugiej, cząsteczki organiczne tej o największej inteligencji, będąc bardziej aktywne i ciaśniejsze, będą się źle łączyć z cząsteczkami drugiej i będą tworzyć luźniejsze i mniej wrażliwe włókna ${ }^{50}$.

Niemniej jednak można kojarzyć mężczyznę silniejszego z kobietą nieco słabsza, aby dzięki temu przekazać dzieciom rozsądek i inteligencję; włókna utworzone częściowo przez delikatne cząsteczki kobiety i częściowo przez silniejsze cząsteczki mężczyzny „stałyby się zdatne do refleksji i dowcipu" ${ }^{\prime 2}$.

Skoro dzieci uczestniczą $\mathrm{w}$ inteligencji i w głupocie ojca i matki, to dziedziczą także ich uczucia, ich skłonności, ich wady i cnoty. „To dlatego prawie zawsze widzimy, że dzieci pochodzące od cnotliwych rodziców noszą w sobie od urodzenia zarodki cnoty, a rozpustni ojcowie płodzą dzieci skłonne do libertynizmu" 52 . Chcąc mieć doskonałe dzieci, należy więc tłumić skłonności do występku i pielęgnować cnoty. Vandermonde sądzi, że przekazywanie złych bądź dobrych cech charakteru zależne jest od tego, które z nich przeważają u przyszłego ojca w czasie oddawania się czynnościom prokreacyjnym. Jeżeli więc nie wszystkie dzieci w rodzinie są skłonne do tych samych wad, to dlatego, że ich ojciec nie zawsze był rozpustny; również dlatego starsze dzieci są bardziej rozpustne niż te później urodzone, ponieważ urodziły się w czasie, gdy ich rodzice byli bardziej namiętni. Vandermonde radzi: „Pożądane byłoby po podążeniu za ogniem młodości odpocząć kilka lat przed ślubem,

50 „Ainsi pour faire des enfants d'esprit, il faudrait être bien construit, avoir des organes fins et délicats, et tâcher de s'unir avec quelqu'un qui ait un dégré d'esprit proportionné au sien. Par ce moyen, l'assemblage des particules organiques se sera beaucoup mieux; car si la force des pensées est la même, il est probable que le ressort est à peu près égal dans les fibres. Au lieu que si dans le mariage l'un des deux individus a un esprit supérieur à l'autre, les molécules organiques de celui qui a le plus d'esprit, étant plus actives, plus serrées, s'engréneront mal avec celles de l'autre individu et formeront des fibres plus lâches et moins sensibles"; Essai, vol. 1: 169-170 [111].

51 "deviendraient susceptibles de réflexions et de saillies"; Essai, vol. 1: 170 [111].

${ }_{52}$ "C'est pourquoi on voit presque toujours les enfants qui viennent de parents vertueux porter en naissant le germe de la vertu, et les pères débauchés donner le jour à des enfants enclins au libertinage"; Essai, vol. 1: 170-171 [111]. 
aby dać naturze czas na powrót do zdrowia i być w stanie dobrze wykonać swe dzieło" ${ }^{53}$. Na szczęście doskonałości jednego z rodziców korygują niedoskonałości drugiego, co zabezpiecza większość dzieci przed konsekwencjami wad ojca lub matki. „W przeciwnym razie słabość narastałaby z każdym dniem wśród ludzi i widzielibyśmy degenerację całej rasy ludzkiej" ${ }^{\prime 54}$.

\section{Oblicze utopii}

Wprawdzie termin „eugenika” w XVIII wieku jeszcze się nie pojawił wprowadzi go Francis Galton w następnym stuleciu - ale oświeceniowi lekarze i myśliciele głoszą wszystko, co tworzy ideologię eugeniki prokreacyjnej w jej dwu aspektach: pozytywnym i negatywnym. W aspekcie pozytywnym nakazuje ona łączyć w pary takie jednostki, co do których zakłada się, że przekażą potomstwu dobre cechy; w aspekcie negatywnym zakazuje łączyć w pary takie jednostki, co do których zakłada się, że przekażą potomstwu złe cechy. W odniesieniu do ludzi ten nakaz i zakaz rozumiane są w sensie etycznym - troska o potomstwo jest naszą powinnością moralną. Ale nie należy jej rozumieć jako ograniczonej jedynie do zapewnienia mu możliwie najlepszych warunków materialnych, właściwego wychowania i wykształcenia; istota postawy eugenicznej wyraża się $\mathrm{w}$ tym, że troska o potomstwo staje się powinnością moralną już na etapie planowania, by je powołać na świat. W następnych stuleciach zakazy i nakazy eugeniczne uzyskają także sens administracyjno-prawny, a działania podejmowane $\mathrm{w}$ trosce o jak najlepsze potomstwo zostaną rozszerzone $\mathrm{z}$ jednostki na społeczność, w skrajnych przypadkach doprowadzając do ustawowych nakazów fizycznej eliminacji osobników uznanych za niegodnych życia i przekazicieli złych genów.

\subsection{Kontekst oświeceniowy}

Eugenika ma starożytne korzenie. Za jej ojca uchodzi Platon (427-347 przed Chr. $)^{55}$, podtrzymywana była przez Soranosa z Efezu (98-138 po

53 „Il serait à souhaiter que l'on pût, après avoir suivi le feu de la grande jeunesse, se reposer plusieurs années avant de se marier, afin de donner à la nature le temps de se refaire, et de pouvoir conduire à bien son ouvrage"; Essai, vol. 1: 173 [112].

54 "Autrement la faiblesse augmenterait tous les jours parmi les hommes, et l'on verrait insensiblement toute l'espèce humaine dégénérer"; Essai, vol. 1: 174 [112].

55 Zob. François-Xavier Ajavon, "Trois exemples historiques d'eugénisme avant Galton (1883): Platon, Soranos \& Vandermonde, (I ème partie)", Vesalius XI, 2 (2005): 70-75. 
Chr. $)^{56}$, ale postać dojrzałą przybrała dopiero w XIX wieku u Francisa Galtona (1822-1911) ${ }^{57}$. Platon wyszedł z założenia, że ludzie, przynajmniej w większości, łączą się w pary kierowani uczuciem, a jeśli biorą pod uwagę uwarunkowania czy względy społeczne bądź ekonomiczne, to nie ma wśród nich racjonalnej kalkulacji co do jakości przyszłego potomstwa. Dlatego jedynym sposobem zapewnienia dobrej jakości potomstwa jest właściwe kojarzenie par, co powinna zapewnić władza państwowa za pomocą stosownej polityki społecznej ${ }^{58}$. W przeciwieństwie do filozofa Platona lekarz Soranos nie zalecał manipulacji społecznej, lecz ograniczał się do medycznej obserwacji, z której wynikają praktyczne wnioski dotyczące żywienia, opieki nad płodem, pielęgnacji niemowląt itp.

Wiek Oświecenia to czas rozwoju projektów eugenicznych. Myśliciele oświeceniowi połączyli postawy Platona i Soranosa, uznając, że ludzi należy wychowywać, by zachowywali się tak, jak przystoi istotom rozumnym, czyli $\mathrm{w}$ tym wypadku zgodnie ze wskazaniami medycznymi. Na znaczenie higieny i wychowania prozdrowotnego zaczęto zwracać uwagę już w XVII stuleciu, choć szybszy był wtedy rozwój wiedzy medycznej niż wzrost poziomu świadomości zdrowotnej ${ }^{59}$. W 1655 roku Claude Quillet (1602-1651), francuski lekarz i poeta łaciński, wydał poemat Callipaedia, seu de pulchrae prolis habende ratione didacticon, propagujący swoistą pedagogikę prozdrowotną. W 1749 roku poemat ten został przełożony na język francuski i odegrał ważną rolę w umacnianiu oświeceniowej świadomości prozdrowotnej i marzeń o lepszym potomstwie ${ }^{60}$.

We Francji, ale także w innych krajach europejskich, coraz częściej dochodzili do głosu lekarze i filozofowie przekonujący, że decyzja o zawarciu związku małżeńskiego w celu wydania na świat potomstwa powinna być podejmowana z uwzględnieniem uwarunkowań biologicznych danej pary i wskazań medycznych, nie powinna zaś być jedynie wypadkową czynników emocjonalnych, zwyczajowych i religijnych ${ }^{61}$.

56 Zob. François-Xavier Ajavon, „Trois exemples historiques d'eugénisme avant Galton (1883): Platon, Soranos \& Vandermonde, (II ème partie)", Vesalius XII, 1 (2006): 25-29.

57 Zob. Roger Sandall, „Sir Francis Galton and the Roots of Eugenics”, Society 45, 2 (2008): 170-176.

58 Zob. Platon, Państwo 458 e-460 a, vol. I, przeł. W. Witwicki (Warszawa: PWN, 1958): 261-264. Platon argumentuje, że wzorem hodowców zwierząt należy tak kojarzyć ludzi w pary, aby "trzoda” (

59 Zob. Maria Nowacka, „Rozwój medycyny a poziom świadomości zdrowotnej w XVII wieku", Roczniki Filozoficzne LXII, 4 (2014): 103-120.

${ }^{60}$ Zob. Jean-Louis Fischer, „La Callipédie ou l'art d'avoir des beaux enfants”, Dixhuitième siècle 23 (1991): 141-158.

${ }^{61}$ Zob. Pinto-Correia, Monteiro, "Science in Support of Racial Mixture”: 20-22. 
Najdobitniej i najobszerniej wyłożył tego rodzaju poglądy Johann Peter Frank (1745-1821), niemiecki i austriacki lekarz, autor sześciotomowego dzieła System einer Vollständigen Medizinischen Polizey, którego pierwszy tom ukazał się w 1779 roku $^{62}$. Szwedzki lekarz Jean-André Venel (17401791), jeden z pionierów ortopedii, w szczególności dziecięcej ${ }^{63}$, w wydanym w 1776 roku traktacie Essai sur la santé et sur l'education médecinale des filles destineés au mariage, podzielając powszechne wówczas przekonanie, że to organizm kobiety ma decydujący wpływ na rozwój jakościowy płodu i narodzonego dziecka - tak jak jakość gleby ma wpływ na jakość plonów - podaje szereg wskazań, jak pod względem zdrowotnym powinny być wychowywane dziewczęta, aby mogły w przyszłości rodzić zdrowe dzieci ${ }^{64}$.

O tym, że właściwy dobór par zwiększa szanse posiadania przez ich potomstwo pożądanych cech psychofizycznych, wiedziano oczywiście od bardzo dawna, dokonując rozmaitych krzyżowań roślin i zwierząt; należało jedynie odnieść tę wiedzę do gatunku ludzkiego. John Gregory (1724-1773), lekarz i moralista, znacząca postać Oświecenia szkockiego ${ }^{65}$, podszedł do tej kwestii z empirycznego punktu widzenia, stawiając platońskie pytanie, dlaczego ulepszamy zwierzęta, a jakość własnego potomstwa pozostawiamy przypadkowi. W dziele A Comparative View of the State and Faculties of Man, with those of the Animal World, którego pierwsze wydanie ukazało się anonimowo w 1765 roku, wyraziście

${ }^{62}$ Twierdził w nim, że ,jednostka nie może podejmować decyzji dotyczących zdrowia społeczeństwa lub ludzkości: po pierwsze, dlatego, że małżeństwo w pewnych okolicznościach może być niekorzystne dla partnera, a nawet śmiertelne; po drugie, ponieważ z takich niezdrowych małżeństw rodzi się niewiele dzieci albo urodzone dzieci stanowią ciężar dla społeczeństwa i umierają wcześnie; i po trzecie, ponieważ jeszcze bardziej zwiększa to przenoszenie chorób dziedzicznych"; cyt. za: Pinto-Correia, Monteiro, Science in Support of Racial Mixture: 20. Istnieje angielski przekład wyboru najważniejszych fragmentów dzieła: Johann Peter Frank, A System of Complete Medical Police: Selections from Johann Peter Frank, ed. with an introduction by E. Lesky (Baltimore: Johns Hopkins University Press, 1976). Podstawowe informacje, z uwzględnieniem koncepcji „policji medycznej”, w: Martin Bloom, „Primary Prevention and the Health of Nations. An Historical Note on Dr. Johann Peter Frank", The Journal of Primary Prevention 23, 1 (2002): 1-6.

${ }_{63}$ Zob. obszerny szkic biograficzny: Jean-François de La Harpe, Jean-André Venel d'Orbe (Lausanne: Imprimerie Marc Ducloux, 1840).

${ }^{64}$ Zob. Jean-André Venel, Essai sur la santé et sur l'education médecinale des filles destineés au mariage (Yverdon: Société Littéraire \& Typographique, 1776). Zwięzłe omówienie poglądów Venela w kwestii wychowania dziewcząt w: Antoinette Emch-Dériaz, "Health and Gender Oriented Education. An Eighteenth-Century Case-Study", Women's Studies 24, 6 (1995): 521-530.

65 Zwięzłe przedstawienie sylwetki w: R. Denis Bastron, Laurence B. McCullough, "What goes around, comes around: John Gregory, MD, and the Profession of Medicine", Baylor University Medical Center Proceedings 20, 1 (2007): 18-21. 
wskazywał tę niekonsekwencję ${ }^{66}$. Z czysto racjonalnego punktu widzenia troska o jakość własnego bydła, realizowana poprzez kojarzenie odpowiednio dobieranych samców i samic, a zarazem brak analogicznego postępowania $\mathrm{w}$ wypadku par ludzkich jawią się jako niezrozumiałe i nierozsądne. Racjonalizm przegrywa jednak w starciu z emocjonalnościa, a zwyczaj lub interes społeczny okazują się silniejsze niż możliwa korzyść biologiczna.

Oświeceniowi racjonaliści uznali, że aby projekt ulepszania gatunku ludzkiego metodami biologicznymi mógł być realizowany dla dobra jednostki i społeczeństwa, konieczne jest spełnienie dwóch warunków. Pierwszy to upowszechnienie przekonania, że relacje międzyludzkie powinny być kształtowane racjonalnie, ponieważ człowiek jest istotą rozumną; myśliciele oświeceniowi usilnie starali się upowszechnić tę postawę jako godną jedynie człowieka. Drugi to uznanie, że cała rzeczywistość jest jednorodnie materialna, a zatem przyczynami wszystkich właściwości i zachowań człowieka są czynniki materialne, organiczne; taka wizja świata dominuje w czasach Oświecenia. W epoce Rozumu ulepszanie człowieka zostaje uznane za powinność moralna, a wiara w jego możliwość oparta jest na wierze w materialną jedność świata.

\subsection{Ku „polityce życia”}

Projekty eugeniczne Vandermonde'a wpisują się w kontekst oświeceniowej troski o jakość psychofizyczną przyszłych pokoleń. Jego dzieło nie zyskało takiego rozgłosu i nie wywarło takiego wpływu, jakiego można byłoby się spodziewać - po części zapewne dlatego, że sam autor żył zbyt $\mathrm{krótko}^{67}$ - a jego projekt nie wyróżnia się na tle oświeceniowych programów eugenicznych w aspekcie wyznaczanym ogólną zasadą, że wskazane jest kojarzenie jednostek jak najzdrowszych i jak najlepiej do siebie pasujących. Jednak znajdują się w jego propozycjach elementy szczególne, nieobecne w zaleceniach innych lekarzy epoki.

${ }^{66}$ „Odpowiedni namysł nad tym pozwoliłby nam ulepszać nie tylko organizm (constitutions), ale i charakter naszego potomstwa. Tymczasem każdego dnia widzimy bardzo rozsądnych ludzi, którzy z troską dbają o zachowanie lub poprawę rasy swoich koni, a skażają krew swoich dzieci i narażają je nie tylko na najbardziej wstrętne choroby ciała, ale i na obłęd, szaleństwo oraz najbardziej niegodne usposobienie; i to także wtedy, gdy nie mogą usprawiedliwiać się, że działali z konieczności lub będąc pod wpływem namiętności"; John Gregory, A Comparative View of the State and Faculties of Man, with those of the Animal World (Edinburgh: J. Johnstone, 1810): 44-45.

67 Tak sądzi redaktor współczesnego wydania traktatu: „Bien que cet ouvrage inaugure une nouvelle façon de concevoir l'homme et ouvre la voie à l'eugénisme moderne, son importance a constamment été sous-estimée, en partie pour des raisons biographiques”; Rudy Le Menthéour, „Introduction”, w: Vandermonde, Essai, 11. 
Nowatorstwo propozycji Vandermonde'a wyraża się w dwóch, powiązanych ze soba, tezach programowych. Po pierwsze, w oparciu o założenie, iż hybrydy międzyrasowe są ludźmi piękniejszymi, czyli lepszymi pod względem psychofizycznym niż ludzie pochodzący od jednej rasy, Vandermonde, w odróżnieniu od współczesnych mu lekarzy ograniczających swe zalecenia do rasy białej, postuluje powszechne realizowanie praktyki małżeństw międzyrasowych. Po drugie, postulat ten faktycznie zostaje sformułowany jako społeczno-polityczny plan mieszania wszystkich ras ludzkich, projektowany przez lekarzy, a realizowany przez władców. Uskutecznianie tych postulatów miałoby prowadzić do rodzenia się lepszych ludzi na całym świecie ${ }^{68}$. Pod tym względem jego poprzednikiem był Pierre-Louis Moreau de Maupertuis (1698-1795), francuski matematyk, fizyk, astronom i filozof, który odwołując się do przykładów z hodowli zwierząt oraz do faktu, że w haremach znajdują się kobiety z różnych ras, sugerował muzułmańskim władcom, aby przeprowadzali stosowne eksperymenty, których rezultatem byłoby wydawanie na świat coraz lepszych ludzi ${ }^{69}$. Vandermonde nie zachęca mężczyzny do prokreacyjnego eksperymentowania z kobietami różnych ras, lecz proponuje globalny plan ulepszania gatunku ludzkiego.

Można widzieć propozycje Vandermonde'a jako prekursorskie względem koncepcji biopolityki, czyli doktryny racjonalnego kształtowania warunków życiowych społeczeństwa i ulepszania jakości psychofizycznej jednostek. Pojawia się wówczas pytanie, czy ta "polityka życia" miałaby być realizowana za pomocą działań zmierzających do czynienia człowieka „normalnym”, a więc przez eliminację anomalii w odniesieniu do uznanej normy, czy za pomocą działań zmierzających do stworzenia człowieka „nad-normalnego", a więc przez ulepszanie

68 „In fact, Vandermonde's main goal was to advocate the widespread practice of interracial marriages as a means to embellish humankind - [...] as a well-established political program of interracial breeding based on the assumption that hybrids are better human beings than people descended from a single race. This point is quite stunning at its inception, since the proposals of other contemporary doctors rested mainly on carefully choosing who to marry to whom in an effort to produce nothing but better white Europeans. In the Essai, on the other hand, we find ourselves dealing mainly with the idea that an equivalent socio-political plan involving the mixing of all known human races, implemented by rulers and designed by doctors, would certainly lead to better human beings worldwide"; Pinto-Correia, Monteiro, Science in Support of Racial Mixture: 22-23.

69 „Pourquoi cet art se borne-t-il aux animaux? Pourquoi ces sultans blasés dans des sérails qui ne renferment que des femmes de toutes les espèces connues, ne se font-ils pas faire des espèces nouvelles?"; Pierre-Louis Moreau de Maupertuis, „Vénus physique", w: Oeuvres de Maupertuis, vol. 2 (Lyon: Bruyset, 1768), 110-111. Maupetuis wskazywał także, iż król pruski mógłby wielce przyczynić się do ulepszenia swego narodu, skoro z takim upodobaniem dobiera do armii jak najdorodniejszych mężczyzn; zob. tamże, 112. 
człowieka w odniesieniu do pożądanego typu idealnego ${ }^{70}$. Vandermonde nie stawia takiego pytania, ale jego rozważania wskazują że kieruje się on jakimś ideałem człowieka, choć nie definiuje go wprost. Idealny człowiek Vandermonde'a to człowiek „,piękny”, zgodny z zaprojektowanym przez Naturę wzorcem, od którego sami, z własnej winy, często bardzo daleko odchodzimy. Ponieważ to piękno obejmuje zarówno właściwą proporcję i ułożenie części ciała, zapewniające dobrostan fizyczny, jak i zdrową psychikę oraz cnotliwy charakter, plan Vandermonde'a jest $\mathrm{W}$ swej istocie umiarkowanym projektem transhumanistycznym ${ }^{71}$. Jak jednak miałby być wprowadzany w życie?

Zalecenia Vandermonde'a miały charakter wyraźnie utopijny - ich realizacja byłaby możliwa tylko z zastosowaniem przymusu. Wprawdzie on sam nie mówił tego wprost, ale swoje sugestie kierował do władzy państwowej ${ }^{72}$. I wkrótce zaczęto się na niego powoływać w uzasadnianiu konieczności stosowania państwowej polityki prokreacyjnej. Francuski ekonomista Joachim Faiguet de Villeneuve (1703-1781) w dziele L'économe politique: Projet pour enricher et pour perfectionner l'espèce humaine, wydanym anonimowo w 1763 roku $^{73}$, porusza kwestię stanu zdrowotnego ludności. Faigueta interesuje ekonomiczny aspekt rozwoju kraju, dlatego formułuje szereg wskazań i zaleceń mających prowadzić do wzrostu potencjału gospodarczego Francji i dobrobytu wszystkich jej mieszkańców. Faktycznie proponuje stworzenie państwa policyjnego, ściśle regulującego wszystkie dziedziny życia społecznego w celu zwiększenia przyrostu naturalnego, wzrostu gospodarczego i poziomu

${ }^{70}$ Zob. Ajavon, „Trois exemples historiques d'eugénisme avant Galton (1883): Platon, Soranos \& Vandermonde, (II ème partie)": 28.

${ }^{71}$ Różnica między radykalnym a umiarkowanym transhumanizmem polega na tym, że ten pierwszy zakłada dokonywanie na człowieku ulepszających zmian jakościowych, a więc prowadzących do stworzenia nowej natury ludzkiej, podczas gdy transhumanizm umiarkowany postuluje dokonywanie jedynie zmian ilościowych, a więc niezmieniających natury człowieka; zob. Benedikt Göcke, „,Moderate Transhumanism and Compassion", Journal of Posthuman Studies 2, 1 (2018): 28-44. Propozycje Vandermonde'a mają prowadzić do odtworzenia pierwotnego, doskonałego wzorca ludzkiej natury, nie zaś do jej zmiany.

72 „Unlike eighteenth-century sex writers, Vandermonde wrote for those doctors and bureaucrats who worried about fertility, the primary agent of state power. For him, the French population urgently needed sexual hygiene, because luxury and libertinism had disrupted natural bonds and caused the species to degenerate"; Quinlan, „Inheriting Vice, Acquiring Virtue”: 660.

${ }_{73}$ Zob. Joachim Faiguet de Villeneuve, L'économe politique: Projet pour enricher et pour perfectionner l'espèce humaine (Londres et Paris: Moreau, 1763). Zwięzłe przedstawienie sylwetki i poglądów Faigueta w: Jacqueline Hecht, „Trois précurseurs de la sécurité sociale au XVIIIe siècle: Henry de Boulainvilliers, Faiguet de Villeneuve, Du Beissier de Pizany d'Eden", Population 14, 1 (1959) (omówienie Faigueta na s. 79-83). Autorka określa poglądy Faigueta jako eugeniczne i socjalistyczne. 
życia ludności, a także poprawy moralności ${ }^{74}$; zaleca zarówno wyższe opodatkowanie osób niemających dzieci, jak i zmuszenie zakonów męskich i żeńskich, aby oprócz bezużytecznego odmawiania modlitw zajęły się także prowadzeniem działalności wytwórczej i intelektualnej pożytecznej dla kraju (choć trzeba przyznać, że nie nakłada na nie obowiązków prokreacyjnych).

Faiguet, powołując się wprost na zalecenia Vandermonde'a, wskazuje na postępującą degenerację ludności kraju, w szczególności klas wyższych, i zaleca, by władze stosowały wzorce uprawy roślin i hodowli zwierząt w odniesieniu do ludzi. „Nasi pisarze polityczni podkreślają że ich celem jest wzrost populacji; wszyscy uważaja, że będzie on najszczęśliwszym owocem doskonałej administracji. Jednak [...] choć bardzo ważne jest, aby ten wzrost zwiększać, [...] o wiele ważniejsze jest jego uregulowanie i udoskonalanie"75. Należy pójść za przykładem papieża Sykstusa V, który zabronił w Rzymie udzielania ślubów parom zbyt ubogim, aby wyżywić i właściwie wychować potomstwo, i zlecił specjalnie powołanym urzędnikom kontrolę przestrzegania tego zakazu. Faiguet zaleca uznanie, że nie tylko stan majątkowy, lecz także stan zdrowia powinien być kryterium zezwolenia na małżeństwo. $\mathrm{Z}$ dezaprobatą zauważa, że policja francuska nigdy nie interesowała się ani zamożnością ani stanem zdrowotnym nowożeńców ${ }^{76}$. A przecież ubóstwo i zły stan zdrowia są ze sobą powiązane, a źle dobrane małżeństwa nie są zdolne do wytwarzania dóbr dla kraju, zwiększania jego dobrobytu czy do wydawania na świat zdrowego potomstwa.

Tworzą one prawie zawsze jedynie skłócone i nieszczęśliwe gospodarstwa domowe, doświadczane przez głód, choroby i smutki. Jakże wiele dzieci wyniszczonych i źle zbudowanych wychodzi z tych związków tak źle do siebie dopasowanych; dzieci skazanych aż do śmierci na życie w ignorancji, szaleństwie, na utrzymywanie się z żebraniny, uciążliwych dla narodu i zdolnych jedynie go hańbićc ${ }^{77}$.

74 Zob. Faiguet de Villeneuve, L'économe politique: 109-153.

75 „Nos auteurs politiques ne cessent de célébrer les avantages de la population; ils la considerent tous come le plus heureux fruit d'une administration parfaite. Cependant, on l'a deja dit, s'il importe beaucoup de l'augmenter, il importe bien plus de la régler et de la perfectioner"; tamże, 119.

${ }_{76}$ „Notre police n'eut jamais d'inquietude sur la fortune ou sur le sort des nouveaux epoux"; tamże, 120.

77 „Ils ne produisent guère que des ménages desunis et maleureux, ménages desolés par la disette, par les maladies et les chagrins. De ces unions si mal concertées, combien sort-il d'enfants debilés et mal constitués; elevés, si la mort n'en delivre la terre, dans l'ignorance, la fénéantise et la mendicité; onéreux par conséquent à la nation, et propres à la deshonorer"; tamże, 121. 
Francuski ekonomista nie formułuje dokładnych wskazań, w jaki sposób miałaby być realizowana w praktyce owa troska o dobrostan zdrowotny kolejnych pokoleń. Zdaje sobie sprawę, że wymaga to nowego, rozbudowanego ustawodawstwa i specjalnie w tym celu powoływanych urzędów; nie ma jednak wątpliwości, że udoskonalanie populacji może być realizowane jedynie na drodze przymusu administracyjnego. „Tutaj, moim zdaniem, otwiera się nowe pole dla naszego prawodawstwa. Ta wielka dziedzina, tak bardzo przez nas zaniedbana, zasługiwałaby jednak na uwagę rządu; być może nie ma takiej, która byłaby bardziej godna tego. Nasza policja powinna zatem stale się tym zajmować i zawsze mieć na celu najszczęśliwszą i najdoskonalszą populację"78. Inaczej mówiąc, szlachetny cel, jakim jest zapewnianie ludziom coraz lepszych warunków życiowych i zdrowotnych, ma być urzeczywistniany za pomocą metod państwa policyjnego.

Charles-Augustin Vandermonde zapewne nie był świadom tego, że wdrażanie jego zaleceń musiałoby prowadzić do tworzenia policyjnej organizacji życia społecznego. W swym dziele nie podaje, w jaki sposób można byłoby skłonić ludzi do kierowania się rozumem w tych sprawach, w których zwykli się oni kierować uczuciami lub emocjami. Czytelnik może jedynie domniemywać, że jego zdaniem możliwe jest takie wyedukowanie obywateli, aby osobiste decyzje, których konsekwencje nie są obojętne dla społeczności, podejmowali racjonalnie. Racjonalne podejmowanie decyzji dokonuje się jednak z uwagi na cel, który chce się osiągnąć, i polega na takim doborze środków, aby cel ten jak najskuteczniej osiągnąć. Dlatego utopia musi ostatecznie sprowadzać się do realizowania planów kreślonych przez utopijnych planistów i prowadzić do zniewolenia tych, których te plany dotyczą ${ }^{79}$. Vandermonde nie czyni refleksji moralnej nad możliwymi konsekwencjami wprowadzania w życie jego zaleceń - jak u każdego utopisty głos jego sumienia został stłumiony mocno brzmiącym wezwaniem, by ulepszać gatunek ludzki ${ }^{80}$. Przykład Vandermonde'a pozwala nam lepiej rozumieć, dlacze-

78 „Voila, ce me semble, un nouveau champ pour notre législation. Ce grand objet, si fort négligé parmi nous, meriterait bien néanmoins l'atention du gouvernement; peut-etre même n'en est-il aucun qui en soit plus digne. Notre police devrait donc s'en ocuper sans cesse, et toujours en suivant les vues d'une population plus heureuse et plus parfaite"; tamże, 151.

${ }_{79}$ Zob. K. R. Popper, Utopia a przemoc, w: tenże, Droga do wiedzy. Domysty i refutacje, tłum. S. Amsterdamski (Warszawa: Wydawnictwo Naukowe PWN, 1999): 590-604.

${ }^{80}$ Na brak u Vandermonde'a refleksji moralnej zwraca uwagę R. Le Menthéour, choć nie wiąże tego z utopijnością myślenia: „Le plus étrange pour un lecteur moderne, ce n'est pas vraiment l'originalité de ces idées, que l'on peut facielment rattacher au contexte intellcctuel de l'époque, mais plutôt l'absence totale de dilemme moral associé au projet d'une manipulation de l'espèce humaine: l'autorité du discours médical y repose sur une rhétorique de l'évidence, où les conclusions pratiques 
go szlachetne intencje czynienia ludzi lepszymi mogą prowadzić do eliminowania ludzi uznanych za gorszych.

\section{Bibliografia}

Ajavon François-Xavier. 2005. „Trois exemples historiques d'eugénisme avant Galton (1883): Platon, Soranos \& Vandermonde, (I ème partie)". Vesalius XI, 2: 70-75.

Ajavon François-Xavier. 2005. „Trois exemples historiques d'eugénisme avant Galton (1883): Platon, Soranos \& Vandermonde, (II ème partie)". Vesalius XII, 1: 25-29.

Bastron R. Dennis, McCullough Laurence B. 2007. „What goes around, comes around: John Gregory, MD, and the Profession of Medicine". Baylor University Medical Center Proceedings 20, 1: 18-21.

Bloom Martin. 2002. „Primary Prevention and the Health of Nations. An Historical Note on Dr. Johann Peter Frank". The Journal of Primary Prevention $23,1: 1-6$.

Bonnot Daniel. 2015. „Les dictionnaires des sciences médicales au XVIIIème siècle. Du dictionnaire de la langue française au dictionnaire médical". Histoire des sciences médicales XL1X, 2: 193-196.

Boxer Charles Ralph. 1973. „A Sino-French Medical Manuscript of 1730”, The Indiana University Bookman 11: 5-11.

Eloy Nicolas-François-Joseph. 1773. Dictionnaire historique de la médecine ancienne et moderne. Mons: H. Hoyois.

Emch-Dériaz Antoinette. 1995. „Health and Gender Oriented Education. An Eighteenth-Century Case-Study". Women's Studies 24, 6: 521-530.

Faiguet de Villeneuve Joachim. 1763. L'économe politique: Projet pour enricher et pour perfectionner l'espèce humaine. Londres et Paris: Moreau.

Fischer Jean-Louis. 1991. „La Callipédie ou l'art d'avoir des beaux enfants”. Dix-huitième siècle 23: 141-158.

Frank Johann Peter. 1976. A System of Complete Medical Police: Selections from Johann Peter Frank, ed. with an introduction by E. Lesky. Baltimore: Johns Hopkins University Press.

Göcke Benedikt. 2018. „Moderate Transhumanism and Compassion”. Journal of Posthuman Studies 2, 1: 28-44.

Gregory John. 1810. A Comparative View of the State and Faculties of Man, with those of the Animal World. Edinburgh: J. Johnstone.

Hecht Jacqueline. 1959. „Trois précurseurs de la sécurité sociale au XVIIIe siècle: Henry de Boulainvilliers, Faiguet de Villeneuve, Du Beissier de Pizany d'Eden". Population 14, 1: 73-88.

La Harpe Jean-François de. 1840. Jean-André Venel d'Orbe. Lausanne: Imprimerie Marc Ducloux.

découlent directement des théories sur l'hérédité"; idem, „Introduction”, w: Vandermonde, Essai, 21. 
Le Menthéour Rudy. 2015. „Introduction”. W: Charles-Augustin Vandermonde, Essai sur la manière de perfectionner l'espèce humaine, 11-31. Paris: Classiques Garnier.

Moreau de Maupertuis Pierre-Louis. 1768. „Vénus physique”. W: Oeuvres de Maupertuis. Vol. 2, Lyon: Bruyset.

Nouveau Dictionnaire historique ou histoire abrégée de tous les hommes qui se sont fait un nom par des talens, des vertus, des forfaits, des erreurs, etc.. 1783. Vol. VIII. Caen: Le Roy.

Nowacka Maria. 2014. „Rozwój medycyny a poziom świadomości zdrowotnej w XVII wieku". Roczniki Filozoficzne LXII, 4: 103-120.

Pinto-Correia Clara, João Lourenço Monteiro 2014. „Science in Support of Racial Mixture: Charles-Augustin Vandermonde's Enlightenment Program for Improving the Health and Beauty of the Human Species". Endeavour 38, 1: 19-26.

Platon. 1958. Państwo, tłum. W. Witwicki. Warszawa: PWN.

Popper Karl R. 1999. Utopia a przemoc. W: Karl R. Popper, Droga do wiedzy. Domysty i refutacje, tłum. S. Amsterdamski. Warszawa: Wydawnictwo Naukowe PWN.

Quinlan Sean M. 2006. „Inheriting Vice, Acquiring Virtue: Hereditary Disease and Moral Hygiene in Eighteenth-Century France". Bulletin of the History of Medicine 80, 4: 649-676.

Rey Roselyne. 1991. „La vulgarisation médicale au XVIIIe siècle. Le cas des dictionnaires portatifs de santé". Revue d'histoire des science 44, 3-4: 413-433.

Sandall Roger. „Sir Francis Galton and the Roots of Eugenics”. Society 45, 2: 170-176.

„Vandermonde (Charles-Augustin)”. 1825. W: Dictionaire des Sciences Médicales. Biographie médicale. Vol. VII. Paris: Éditeur C. L. F. Panckoucke.

Vandermonde Charles-Augustin. 1760. Dictionnaire portatif de santé, nouvelle édition. Paris: Vincent.

Vandermonde Charles-Augustin. 1756. Essai sur la manière de perfectionner l'espèce humaine. Vol. I-II. Paris: Vincent.

Vandermonde Charles-Augustin. 2015. Essai sur la manière de perfectionner l'espèce humaine. Edition de Rudy Le Menthéour. Paris: Classiques Garnier.

Venel Jean-André. 1776. Essai sur la santé et sur l'education médecinale des filles destineés au mariage. Yverdon: Société Littéraire \& Typographique.

Vila Anne C. 1998. Enlightenment and Pathology. Sensibility in the Literature and Medicine of Eighteenth-Century France. Baltimore and London: The Johns Hopkins University Press.

Winston Michael. 2005. „Medicine, Marriage, and Human Degeneration in the French Enlightenment". Eighteenth-Century Studies 38, 2: 263-281.

Zeller Olivier. 2006. „Médecine des Lumières et risques professionnels: le Dictionnaire portatif de santé". W: Le travail avant la Révolution industrielle, Actes du 127e congrès des Sociétés Historiques et Scientifiques, Nancy, 2002, ed. Maurice Hamon, 127-137. Paris: CTHS. 


\section{Streszczenie}

W artykule przedstawiono życie i działalność Charlesa-Augustina Vandermonde'a, w szczególności jego propozycje ulepszania rodzaju ludzkiego poprzez właściwe kojarzenie małżeństw. Podkreślono nowatorski aspekt jego eugeniki wyrażający się $\mathrm{w}$ postulacie łączenia w pary osób odmiennych ras, co miało zwiększać prawdopodobieństwo wydania na świat dobrego potomstwa. Wskazano na utopijny charakter proponowanych działań.

Słowa kluczowe: Vandermonde, historia medycyny, eugenika, utopia

\section{Charles-Augustin Vandermonde (1727-1762) and His Eugenic Utopia}

\section{Summary}

The article presents the life and activities of Charles-Augustin Vandermonde, in particular his proposals to improve the human race through the proper matching of marriages. The innovative aspect of his eugenics was emphasized in the postulate of pairing people of different races, which was to increase the likelihood of producing good offspring. The utopian nature of the proposed actions was pointed out.

Keywords: Vandermonde, history of medicine, eugenics, utopia 